\title{
ALTERNATIF DESAIN RUMAH TUMBUH MODULAR SISTEM PRE-FABRIKASI RISHA
}

\author{
Muhammad Nelza Mulki Iqbal \\ Dosen Prodi Arsitektur, Fak. Teknik Sipil dan Perencanaan, ITN Malang \\ e-mail: nelzamiqbal@lecturer.itn.ac.id \\ Bayu Teguh Ujianto \\ Dosen Prodi Arsitektur, Fak. Teknik Sipil dan Perencanaan, ITN Malang \\ e-mail: bayu_teguh@lecturer.itn.ac.id
}

\begin{abstract}
ABSTRAK
Menurut data Bappenas dan BPS, backlog atau kekurangan penyediaan rumah di Indonesia mencapai kisaran angka 800.000-1.000.000 setiap tahunnya. Selain permasalahan kekurangan penyediaan rumah, Indonesia juga dihadapkan dengan tingginya harga rumah terutama pada lahanlahan perkotaan. Karenanya diperlukan sebuah strategi pengembangan penyediaan rumah secara bertahap, yang diharapkan mampu menurunkan harga rumah sekaligus meningkatkan daya beli rumah. RISHA merupakan sistem modular prefabrikasi rumah yang sudah cukup lama dikembangkan oleh Kementeian Pekerjaan Umum, namun di lapangan RISHA belum berhasil menciptakan minat beli yang masif. Karenanya penelitian ini mencoba membedah penggunaan RISHA pada kasus rumah tumbuh modular dan menyajikan alternatif desain berdasarkan kriteria agemilestone yang menghasilkan alternatif hunian single, married, dan family. Metode penelitian yang digunakan adalah penelitian kualitatif dengan menggunakan beberapa tahapan diantaranya studi literatur, studi eksplorasi bentuk, dan proses desain skematik. Pada tahapan desain skematik peneliti mengaplikasikan proses design thinking yang dikembangkan oleh IDEO yakni lima langkah mendesain melalui discovery, interpretation, ideation, experiment, dan evolution. Keluaran dari desain berbasis riset ini diharapkan mampu menampilkan gagasan eksploraritf RISHA untuk pengembangan strategi rumah tumbuh di Indonesia
\end{abstract}

\section{Kata kunci: Modular, Pre-Fabrikasi, RISHA, Rumah Tumbuh}

\begin{abstract}
According to Bappenas and BPS's data, the backlog of housing supply in Indonesia reaches the range of 800,000-1,000,000 each year. Apart from the shortage of housing supply problems, Indonesia is also faced with high housing prices, especially on urban area. Therefore, we need a strategy to develop housing provision using incremental strategy, which is expected to be able to reduce house prices while increasing the purchasing power of customera. RISHA is a modular prefabricated house system that has been developed for a long time by the Ministry of Public Works, but in reality RISHA has not succeeded in creating massive buying interest. Hence, this
\end{abstract}

PAWON: Jurnal Arsitektur, Nomor 01 Volume V, Januari - Juni Tahun 2021, ISSN 2597-7636 
article tries to dig in the use of RISHA in the case of modular incremental housing and presents design alternatives based on the age-milestone criteria which are categorized as single, married, and family. The research method used is a qualitative research using several stages including literature study, exploration study, and schematic design process. At the schematic design stage, the researcher applies the design thinking process developed by IDEO, including five design stepts: discovery, interpretation, ideation, experiment, and evolution. The output of this research-based design is expected to be able to present RISHA's exploratory ideas for the development of incremental housing strategy in Indonesia.

\section{Keywords: Modular, Pre-Fabrication, RISHA, Incremental House}

\section{PENDAHULUAN}

Laju pertumbuhan penduduk Republik Indonesia berdasarkan catatan BPS, pada tahun 2010-2020 berkisar pada angka 1,31 persen (BPS, 2020). Meskipun di klaim melambat namun jika kita melihatlebih detil angka rerata pertambahan penduduk pada 2010-2010 mencapai kisaran 3,26 juta jiwa per tahunnya. Pertumbuhan penduduk, selalu berhubungan dengan munculnya peningkatan kebutuhan utama seperti sandang, pangan dan papan. Hal ini tentunya akan berimplikasi pada tingginya permintaan akan rumah di Indonesia. Dirjen Pembangunan Daerah Kementrian Dalam Negeri mencatat angka backlog rumah di Indonesia pada tahun 2015 sebesar 13,5 juta unit dengan kebutuhan perumahan tiap tahunnya mencapai angka 800.000 hingga 1.000.000 rumah tiap tahunnya (Ningrum, 2017).

Untuk mengatasi masalah ini Pemerintah sudah mencoba mengaplikasikan beberapa skema penyediaan rumah sepertu Program Sejuta Rumah, meskupun realiasi dilapangan belum maksimal dikarenakan aspek perizinan, penyediaan lahan, ketersediaan anggaran dan skema pembiayaan (Ningrum, 2017). Dengan target memangkas angka defisit backlog menjadi lebih rendah kedepannya diperlukan strategi taktis yang applikatif sehingga tantangan belum maksimalnya program penyediaan rumah oleh pemerintah dapat terjawab. Salah satu strategi yang menarik untuk ditindak lanjuti adalah strategi pembangunan rumah tumbuh. Rumah tumbuh merupakan pembangunan rumah bertahap baik horizontal maupun vertikal yang dilandaskan pertambahan penghuni dan aktifitas (Raihan \& Suthan, 2020).

Terkait upaya penyediaan model rumah tumbuh, pemerintah melalui Puslitbang Permukiman, Kementerian Pekerjaan Umum dan Perumahan telah menghasilkan teknologi rumah instan sederhana yang diberi nama RISHA (Rumah Instan Sederhana Sehat) (Puskim, 2015). Teknologi yang ditawarkan berupa teknologi struktur beton pra cetak/pre-cast/pre-fabrikasi dengan sistem knockdown, yang bertujuan untuk mempersingkat waktu pemasangan, menjamin mutu kualitas kehandalan bangunan dan 
mempermudah pembangunan rumah. Inovasi RISHA ini telah diterapkan dibeberapa lokasi di Indonesia seperti di Aceh beberapa waktu setelah terjadi bencana alam gempa bumi dan tsunami, di Palembang untuk perumahan-perumahan swasta, dan beberapa tempat lainnya (Sabarudin, 2006).

Sayangnya selama ini studi tertulis mengenai RISHA masih terbatas, dan kebanyakan hanya berkutat pada aspek struktural dan keandalan bangunan. Studi penggunaan RISHA sebagai alternative rumah tumbuh di Indonesia dengan alternative desain yang baik dan layak secara desain arsitektural masih sulit untuk ditemui. Penelitian ini mencoba memberikan alternative gagasan desain arsitektural rumah risha dengan mengedepankan prinsip estetika desain dan perencanaan. Kedua aspek ini akan mengacu pada pola tumbuh dan pengembangan rumah yang didasarkan pola aktivitas penghuni rumah dan juga bertambahnya kebutuhan fungsional dikarenakan penambahan jumlah anggota keluarga serta pendapatan. Sebagai konseptual rumah tumbuh, penelitian ini mencoba melakukan uji simulasi desain rumah tumbuh modular menggunakan RISHA yang didasarkan pada age-milestone penghuni rumah dengan tiga kategori utama yakni single, married, dan family.

Memetakan potensi RISHA sebagai salah satu alternative membangun rumah yang bertumbuh diharapkan bisa menjadi solusi kekurangan back-log perumahan di Indonesia. Asumsi ini didasarkan pada kajian ekonomi RISHA yang menawarkan sebuah konstruksi murah dan berkelanjutan (Sabaruddin, 2006). Kehadiran alternatif gagasan desain yang menarik pada penggunaan material RISHA tentunya akan berkontribusi memperkenalkan penggunaan struktur ini agar dapat digunakan lebih banyak lagi.

\section{TINJAUAN PUSTAKA}

\section{Teknologi RISHA}

RISHA merupakan varian dari beton pracetak atau precast yang sampai saat ini terus dikembangkan oleh Kementerian Pekerjaan Umum dan Perumahan Rakyat melalui Pusat Penelitian dan Pengembangan Permukiman. RISHA sendiri merupakan istilah yang dipopulerkan Kemeterian PU yang merupakan akronim dari Rumah Instan Sederhana Sehat. Teknologi yang diusung RISHA merupakan konstruksi rumah layak huni dengan sistem bongkar pasang atau knock-down. Setiap modul lengkap RISHA berukuran $3 \times 3 \mathrm{M}$ yang bisa dirangkai hanya dalam jangka waktu 24 Jam dengan menggunakan 3 orang pekerja. RISHA memiki tiga komponen panel struktur utama yang diidentifikasikan dengan struktur P1, P2, dan P3. Dengan menggunakan struktur dasar ini maka dapat diperoleh bangunan yang cepat, murah, ramah lingkungan, dapat dipindah, ringan,

PAWON: Jurnal Arsitektur, Nomor 01 Volume V, Januari - Juni Tahun 2021, ISSN 2597-7636 
dan bisa di modifikasi (PUSKIM, 2015). Karena keunikannya ini, teknologi RISHA bahkan dapat dipergunakan sebagai material utama untuk keperluan pembangunan atau rekonstruksi bangunan pasca bencana seperti pada saat Gempa Bumi Tahun 2018 di Nusa Tenggara Timur (Faiz, 2018).

Komponen struktural merupakan komponen utama untuk mendukung berdirinya suatu bangunan. Jikalau komponen ini dihilangkan maka bangunan tidak akan berfungsi dan berdiri sebagaimana mestinya. Bangunan utuh membutuhkan setidaknya tiga komponen struktural utama yakni pondasi, rangka, dan atap. RISHA sendiri dengan ketiga struktur P1, P2, P3 merupakan bagian dari sistem rangka yang berhubungan langsung dengan aktifitas utama bangunan sebagai penyedia ruang.

Komponen struktur RISHA terdiri dari 2 buah balok beton berukuran panjang 1,2 meter (Panel 1 dan Panel 2) dan 1 buah beton simpul yang menyerupai kubus berukuran $30 \mathrm{~cm}$ yang disebut Panel 3 . Seluruh komponen RISHA dihubungkan dengan baut dan pelat galvanis yang tahan korosi. Panel struktur yang terbuat dari beton berfungsi menahan gaya tekan pada komponen RISHA, sedangkan baja berguna untuk memikul beban gaya tarik pada struktur. Jika dirangkai, komponen balok dan simpul beton kerangka kubus beton, dan menciptakan sebuah ruang berukuran panjang dan lebar masing-masing 3 meter $(3 \times 3)$. Dari luasan ini sebenarnya dihasilkan ketinggian bersih bangunan 3,6 meter dan luasan bersih ruang 2,4 meter. Dipasaran harga paket panel risha $3 \times 3$ berada pada angka Rp. 5.960.000, dengan perincian detil harga P1, P2, dan P3 antara 120-150rb.
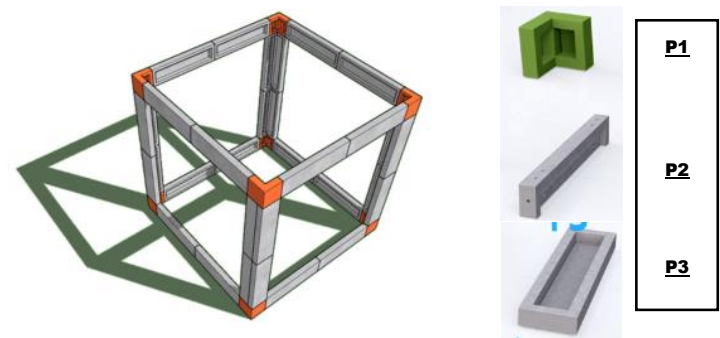

Gambar. 1

Komponen RISHA

Sumber: Perkim, 2015

\section{Rumah Tumbuh}

Tuntutan ekonomi dan ketidakpastian masa depan termasuk didalamnya mengenai ketidakpastian karir dan terutama jumlah penghuni membuat banyak pihak mulai memikirkan alternative rumah tumbuh sebagai pilihan (Schneider \& Till, 2007). Membangun rumah secara bertahap sesuai dengan kemampuan keuangan dan kebutuhan ruang untuk masa sekarang dan masa depan sudah saatnya menjadi trend dalam perumahan dan permukiman di Indonesia. Dengan perencanaan lebih awal kebutuhan 
mengembangkan rumah sebagai rumah tumbuh bisa lebih terukur dan terarah. Kondisi yang terjadi lapangan banyak rumah dan perumahan yang dihasilkan oleh pengembang dipaksa untuk ditumbuhkan karena memang tidak sedari awal didesain sebagai rumah tumbuh (Akmal, 2011). Hal ini tentunya berdampak pada membengkaknya biaya pengembangan rumah juga tidak terarahnya pembangunan rumah baik secara desain dan perencanaan. Rumah tumbuh merupakan suatu cara yang tepat dan ringan bagi mereka yang berpenghasilan kecil dan berminat membangun rumahnya secara bertahap (Dewi, 2007). Secara prinsip rumah tumbuh mencakup beberapa hal diantaranya perencanaan terukur, berorientasi ke masa depan terhadap kebutuhan ruang, tampak bangunan tetap estetis, tahapan pembangunan tidak mengganggu yang sudah ada.

Rumah tumbuh dapat diawali dari perencanaan desain yang matang agar dapat menampung perkembangan kebutuhan rumah di masa depan (Wijaya, 2006). Pengembangan rumah dengan konsep rumah tumbuh dapat dilakukan melalui pertimbangan ketersediaan lahan dan persiapan konstruksi bangunan. Desain rumah awal minimal dapat mewadahi aktivitas dasar manusia dalam rumah yang apabila mengacu pada Pedoman Umum Rumah Sehat Sederhana mencakup beberapa aktivitas yakni makan, kerja, duduk, tudur, mandi, cuci, kakus, masak, dan ruang gerak lainnya. Pedoman ini juga mensyaratkan minimal kebutuhan ruang per orang setidaknya $9 \mathrm{~m} 2$, sehingga bertambahnya jumlah hunian akan bisa langsung di akumulasikan dari luasan dasar ini.

Pembahasan rumah tumbuh juga terkait dengan kebutuhan tipe hunian berdasarkan umur dan status kepala keluarga. Sehingga terdapat pentahapan karir kepemilikan rumah atau yang lebih dikenal dengan housing career. Kecenderungan preferensi rumah berdasarkan umur dan status ini sangat bermanfaat untuk menyelesaikan kekurangan kebutuhan rumah di Indonesia. Meskipun pada pengaplikasiannya pasti ditemui banyak kendala karena memang belum terbiasanya masyarakat Indonesia untuk memiliki rumah berdasarkan kebutuhan dan bisa berkembang seiring berjalannya waktu, bertambahnya anggota keluarga, dan kenaikan pendapatan. Menurut satu studi mengenai housing career di Kota Bandung terdapat beberapa tahapan ketika seseorang memutuskan membeli atau membangun rumahnya (Rosa, 2016). Pertama tahapan sebelum menikah pada rerata umur 20-23, yang merupakan tahapan dimana seseorang memutuskan bekerja dan mulai melepas ketergantungan terhadap orang tua. Kedua tahapan menikah dan memiliki anak pada rentang usia 25-27 tahun. Hal yang menarik dari penelitian ini adalah rentang waktu seseorang mulai memutuskan punya rumah sendiri adalah pada usia 30-31 tahun dimana membutuhkan antara 4-6 tahun dari usia pernikahan untuk memiliki rumah sendiri.

PAWON: Jurnal Arsitektur, Nomor 01 Volume V, Januari - Juni Tahun 2021, ISSN 2597-7636 


\section{METODE PENELITIAN}

Penelitian ini menggunakan pendekatan deskriptif kualitatif dengan memberikan gambaran tertulis terkait potensi penggunaan struktur RISHA dalam memenuhi kebutuhan rumah tumbuh di Indonesia. Sedangkan metode penelitian yang digunakan dalam penelitian ini adalah analisa data sekunder yang berasal dari penelitian-penelitian terdahulu. Dalam penelitian mengenai RISHA sebagai alternative rumah tumbuh modular di Indonesia, terdapat beberapa langkah yang akan ditempuh, yaitu:

\section{Studi Literatur}

Tahapan ini digunakan untuk mengetahui karakter RISHA dan konsepsi rumah tumbuh. Langkah ini diperlukan untuk mengetahui lebih mendalam tentang rumah RISHA dan potensinya sebagai alternative rumah timbuh. Studi literatur dilakukan untuk mendapatkan pengetahuan mengenai karakterisik, teknik, prinsip dan teknik serta contoh implementasi dari obyekkajian.

\section{Eksplorasi Studi Kasus}

Dalam mengungkapkan alternative desain menggunakan RISHA maka diperlukan penelusuran terkait hasil desain terbangun pada kasus bangunan yang menggunakan RISHA termasuk memberikan analisa mengenai hasil desain terbangun seingga bisa menjadi masukan dalam menghasilkan desain alternative RISHA nantinya.

\section{Proses Desain Skematik}

Adalah sebuah proses yang dilakukan perancang dalam hal ini arsitek melalui sajian data berupa gambar sketsa dan modeling baik secara manual maupun dugutal sehingga dapat memberikan gambaran hasil perancangan yang sesuai dengan kriteria, fungsi, dan estetika yang baik. Pada tahapan ini peneliti akan mengaplikasikan proses design thinking yang dikembangkan oleh IDEO (2011) yakni lima langkah mendesain melalui discovery, interpretation, ideation, experiment, dan evolution.

\section{HASIL DAN PEMBAHASAN}

Membangun rumah tumbuh tidak sama halnya dengan membangun rumah kecil, rumah tumbuh memberi ruang berkembang untuk penghuninya sendiri (Wainer, et. al, 2016). Rumah tumbuh Tujuan utamanya adalah menekan biaya pembangunan di awal sehingga biaya ini bisa dialokasikan pada pemilihan lokasi yang tepat. Lokasi juga menjadi kata kunci utama pada studi lain (Aravena, 2011; Grene \& Rojas, E, 2008). Kriteria berikutnya menyangkut pada area inti (core house), dimana area ini akan menjadi titik tolak awal pengembangan rumah tumbuh. Selanjutanya tentu saja area expansi, bagaimana secara konseptual perancangan rumah tumbuh 
memiliki ruang untuk berkembang sesuai dengan perencanaan di awal. Sehingga paling tidak untuk perencanaan rumah tumbuh ada tiga kriteria yang perlu menjadi pertimbangan yakni lokasi, area inti, dan area expansi.

Melalui pencarian studi literatur lanjutan maka konsepsi rumah tumbuh modular ini akan di layer dengan titik loncatan umur pengguna (agemilestone) yang mengacu pada konsepsi berhuni Housing Career (Rosa, 2016). Sehingga didapatkan tiga output alternatif desain berdasarkan milestone yang dicapai calon penghuni berawal dari tipe single, couple, dan family. Untuk kriteria lokasi, karena sifat studi ini adalah eksploratif maka pembatasan lokasi tidak bergantung pada ketepatan dan seberapa bagus lokasi perencanaan rumah tumbuh. Namun, gagasan desain ini lebih mengunci pada minimal lahan minimal yang bisa diolah menjadi skema desain rumah tumbuh yang optimal dan efisien pada masing-masing kriteria. Sehingga luasan $60 \mathrm{~m} 2$, dipilih sebagai luas minimal untuk kategori rumah sederhana tapak di Indonesia (Suryo, 2017).

Alternatif desain pertama untuk tipe single (Gambar 2), memiliki area inti berupa modul kamar tidur dan modul kamar mandi dengan luas kotor masing-masing $9 \mathrm{~m}^{2}$ dan $5,4 \mathrm{~m}^{2}$ sehingga total luasan area inti adalah lebih kurang $15 \mathrm{~m}^{2}$. Pada alternatif desain ini area expansi cukup terbuka baik secara vertikal maupun horizontal. Ruang-ruang yang diwadahi pada kriteria pertama adalah ruang tidur, dapur kecil, dan kamar mandi. Pada alternatif desain ini, rekomendasi penggunaan atap dan fasad onduline muncul untuk memberikan nilai modern dan estetis juga berkelanjutan karena bisa digunakan untuk ekspansi pada tipe hunian berikutnya.

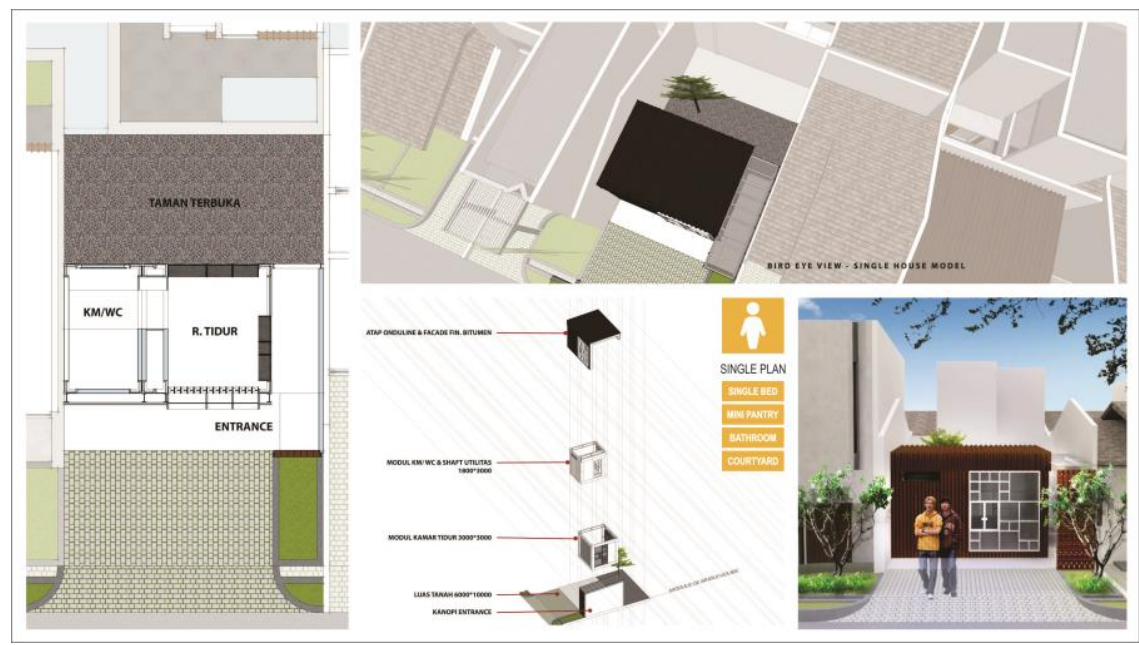

Gambar. 2

Alternatif Desain Rumah Tumbuh Tipe Single

Sumber: Analisa, 2020

PAWON: Jurnal Arsitektur, Nomor 01 Volume V, Januari - Juni Tahun 2021, ISSN 2597-7636 
Alternatif desain kedua adalah tipe couple (Gambar 3), dimana diasumsikan pengguna mulai berkeluarga sehingga membutuhkan expansi ruang yang lebih besar. Area inti mengalami expansi dengan penambahan modul ruang keluarga. Sehingga total luasan akan bertambah mengikuti jumlah modulasi ruang yakni modul ruang keluarga $9 \mathrm{~m}^{2}$, ruang tidur $9 \mathrm{~m}^{2}$, modul dapur 5,4 $\mathrm{m}^{2}$ dan modul kamar mandi 5,4 $\mathrm{m}^{2}$. Maka diperolehlah luasan lebih kurang $30 \mathrm{~m}^{2}$. Adapun ruang-ruang yang diwadahi pada konsep desain ini adalah ruang tidur, ruang keluarga, dapur, kamar mandi, dan ruang bersantai outdoor.

Alternatif desain ketiga adalah tipe family (Gambar 3), dimana diasumsikan pengguna mulai memiliki anggota keluarga inti baru sehingga membutuhkan expansi ruang yang lebih besar. Area inti mengalami expansi dengan penambahan modul tangga, dan kamar tidur anak. Sehingga total luasan akan bertambah mengikuti jumlah modulasi ruang yakni modul ruang keluarga $9 \mathrm{~m}^{2}$, modul tangga $9 \mathrm{~m}^{2}$, modul dapur $5,4 \mathrm{~m}^{2}$, modul kamar mandi $5,4 \mathrm{~m}^{2}$., modul kamar utama $9 \mathrm{~m}^{2}$, modul kamar anak $10,4 \mathrm{~m}^{2}$ dan modul void tangga $9 \mathrm{~m}^{2}$. Maka diperolehlah luasan lebih kurang $60 \mathrm{~m}^{2}$ Adapun ruang-ruang yang diwadahi pada konsep desain ini adalah ruang tidur, ruang keluarga, dapur, kamar mandi, ruang bersantai outdoor, ruang servis tangga, dan ruang tidur anak.

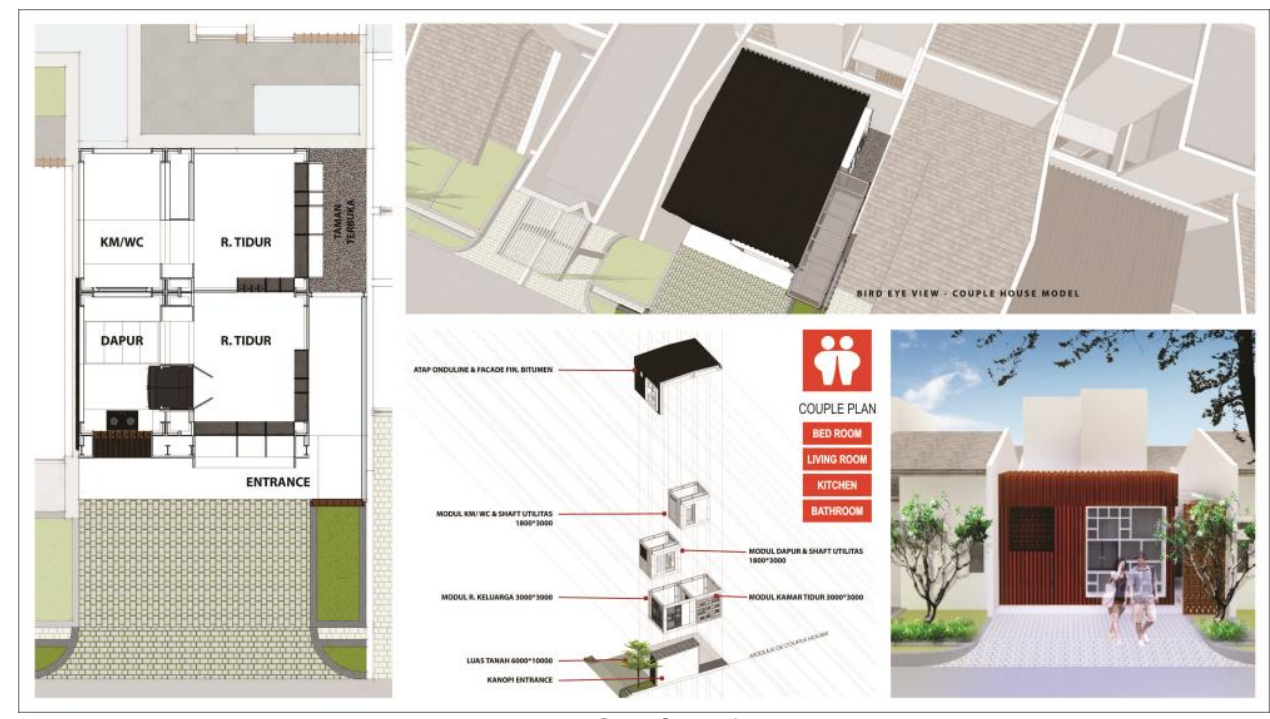

Gambar. 3

Alternatif Desain Rumah Tumbuh Tipe Couple

Sumber: Analisa, 2020 


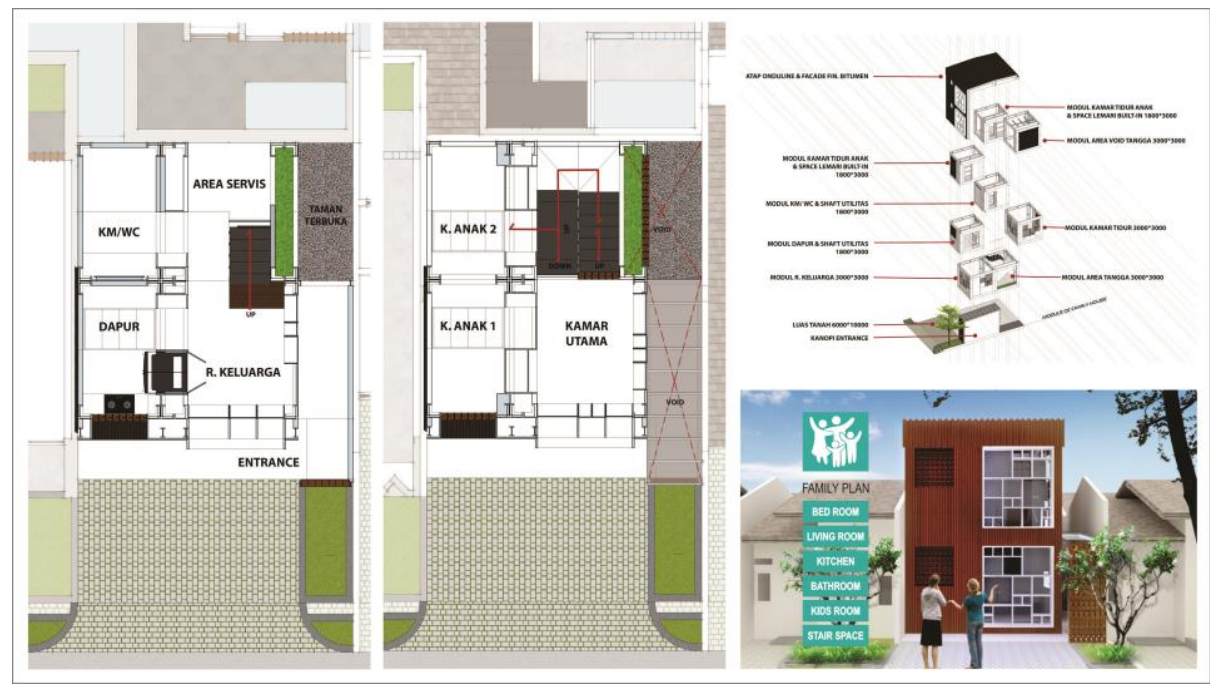

Gambar. 4

Alternatif Desain Rumah Tumbuh Tipe Family

Sumber: Analisa, 2020
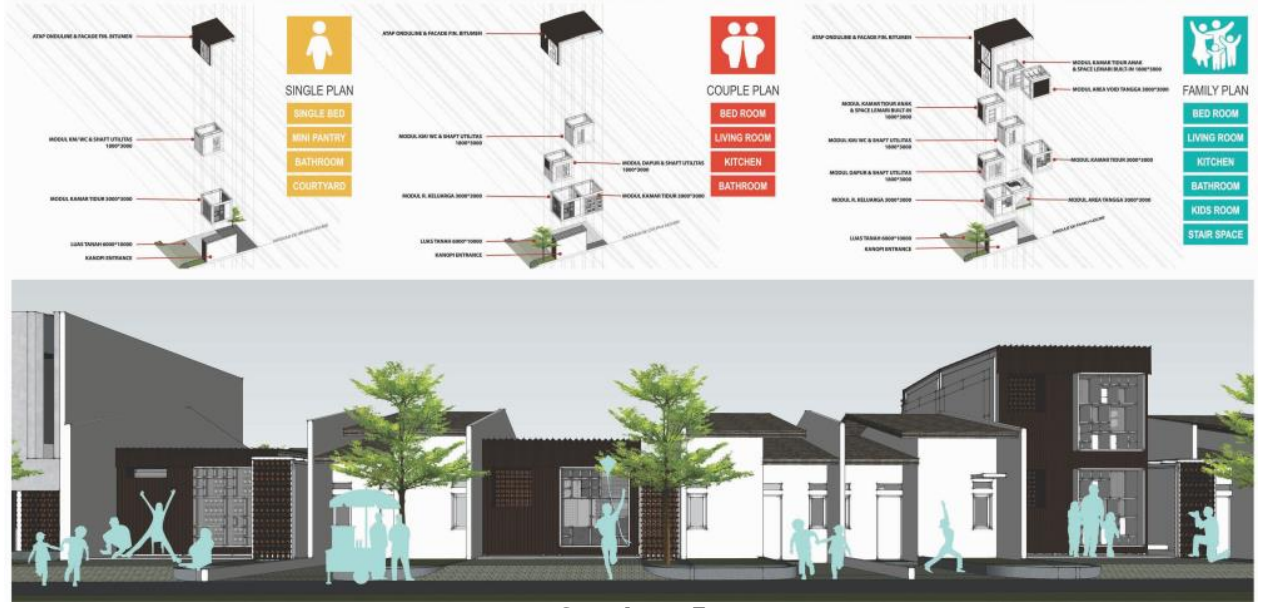

Gambar. 5

Perbandingan Alternatif Desain Rumah Tumbuh Sumber: Analisa, 2020

\section{KESIMPULAN}

Berdasarkan proses desain yang telah dilakukan terdapat tiga kriteria perancangan rumah tumbuh yang perlu diperhatikan yakni lokasi, area inti, dan area ekspansi. Gagasan rumah tumbuh modular menggunakan sistem pre-fabrikasi RISHA, membuka peluang dan kreatifitas untuk dikembangkan menjadi salah satu ujung tombak strategi rumah tumbuh di Indonesia. Secara prinsip rumah tumbuh mencakup beberapa hal diantaranya perencanaan terukur, berorientasi ke masa depan terhadap kebutuhan

PAWON: Jurnal Arsitektur, Nomor 01 Volume V, Januari - Juni Tahun 2021, ISSN 2597-7636 
ruang, tampak bangunan tetap estetis, tahapan pembangunan tidak mengganggu yang sudah ada. Salah satu alernatif pentahapan dalam rumah tumbuh mengadopsi titik tolak usia (age-milestone) sehingga rumah tumbuh bisa dikembangkan berdasarkan pencapaian-pencapaian fase tertentu pengguna. Age-milestone sendiri membagi tiga tahapan utama yakni single, couple dan family. Ketiga alternatif desain ini diikuti pengolahan ruang yang fleksibel dengan modulasi tertentu sehingga memudahkan untuk dilakukan expansi dari desain core awalnya.

\section{DAFTAR PUSTAKA}

Akmal, I. (2011). Serial IDE: 20 Desain Inspirartif Rumah Tumbuh Tipe 45-68m2. Jakarta: Gramedia Pustaka Utama.

Aravena, A. (2011). The Forces in Architecture. Tokyo : Toto Publishing.

BPS. (2020). Potret Sensus Penduduk 2020 . Jakarta: Badan Pusat Statistik.

Dewi, N. (2007). Rancangan Rumah Tumbuh Tipe KPR BTN Denpasar. Prosiding PESAT Univesitas Gunadarma Denpasar. Denpasar: Univesitas Gunadarma

Faiz, S. (2018). Rekonstruksi Fasilitas Pendidikan Pasca Bencana Gempa Bumi Tahun 2018 di Kabupaten Sumbawa Provinsi NTB Menggunakan Konstruksi RISHA. Cantilever: Jurnal Penelitian dan Kajian Bidang Teknik Sipil.

Grene, M., \& Rojas, E. (2008). Incremental Construction: A Strategy to Facilitate Access to Housing. London: International Institute for Environment and Development.

IDEO. (2011). Design Thinking for Educatore. London: IDEO.

Ningrum, D. A. (2017, September 28). Kebutuhan Rumah Per tahun Mencapai 1 Juta Unit. Retrieved from https://www.merdeka.com/uang/kebutuhan-rumahper-tahun-mencapai-1-juta-unit.html

Puskim. (2015). Modul RISHA (Rumah Instan Sederhana Sehat) . Bandung: Balitbang Kementrian Pekerjaan Umum dan Perumahan.

Raihan, M., \& Sulthan, F. (2020). Penerapan Konsep Rumah Tumbuh Pada Teknologi Struktur RISHA. Seminar Nasional Avoer XII (pp. 355-362). Palembang: Fakultas Teknik Universitas Sriwijaya.

Rosa, Y. (2016). Kebutuhan Tipe Hunian Berdasarkan Umur dan Status Kepala Keluarga. Jurnal Permukiman , 11(2), 88-89.

Sabarudin, A. (2006). Membangun RISHA, Rumah Instan Sehat Sederhana. Jakarta: Penerbit Griya Kreasi.

Schneider, T., \& Till, J. (2007). Flexible Housing. London: Taylor \& Francis.

Suryo, M. S. (2017). Analisa Kebutuhan Luas Minimal pada Rumah Sederhana Tapak di Indonesia. Jurnal Permukiman , 116-123.

Wainer, L., Ndengeioma , B., \& Murray, S. (2016). Inccremental Housing and Other Design Principles for Low Cost Housing. London: Toto Publishing.

Wijaya, F. (2006). Cara Mensiasati Pengembangan Rumat Tumbuh. Jakarta: Majalah Estate. 